Jurnal Media Komunikasi Pendidikan Pancasila dan Kewarganegaraan

Volume 2, Nomor 1 April 2020

\title{
PERAN MAHKAMAH KONSTITUSI DALAM PEMILU
}

\author{
Kadek Dwiky Astawa \\ Jurusan Hukum dan Kewarganegaraan \\ Fakultas Hukum dan Ilmu Sosial \\ Universitas Pendidikan Ganesha, Singaraja
}

\begin{abstract}
Abstrak
Konstituai sebagai hukum tertinggi lahir sebagai untuk melindungi hak-hak asasi manusia. Konstitusi merupakan keseluruhan peraturan-peraturan baik tertulis maupun tidak tertulis yang mengatur secra mengikat tentang cara penyelenggaraan pemerintah dalam suatu negara. Dalam kaitanya hak warga negara dalam bidang politik, penyekenggaraan pemilu sangat erat kaitanya dengan persoalan HAM. Perlindungan HAM akan membawa suatu pemilu yang demokratis, Mahkamah Konstitusi yang melalui putusannya tentang berperan dalam suatu pelaku kekuasaan kehakiman yang memberikan perlindungan HAM. Mahkamah Kontitusi berfungsi sebagai pengawal dan penafsiran konstitusi, selain itu MK juga berfungsi sebagai pengawal demokrasi, perlindung hak konsitusional warga negara dan perlindungan HAM. Perlindungan hak asasi manusia merupakan salah satu fungsi dari MK yang merupakan konsekuensi dari keberadaan HAM sebagai materi muatan konsitusi. Dalam melindungi HAM, MK dapat melihat pada beberapa putusan baik dalam perkara pengujian Undangundang maupun perselisihan hasil pemilu diantaranya adalah pemulihan hak pilih bekas anggota PKI, hak pilih mantan narapidana tertentu, pemberian hak pencalonan kepada parati non parlemen, hak percalonan kepada perseorangan dalam pemilukada, perlindungan hak bagi pertahanan, hak pilih ancaman dan terror, perlindungan hak mencalnkan diri tindakan yang menghambat, serta pengakuan terhadap cara yang diakui oleh hukum adat.
\end{abstract}

Kata Kunci : Peran, Mahkamah, Konstitusi, Pemilu

\begin{abstract}
Constituency as the highest law was born as to protect human rights. The constitution is the entire written and unwritten regulations that regulate securely about how the administration of government in a country. In relation to the rights of citizens in the political field, the holding of elections is closely related to the issue of human rights. Protection of human rights will bring a democratic election, the Constitutional Court which through its ruling about playing a role in an actor of judicial power that provides human rights protection. The Constitutional Court functions as a guardian and interpreter of the constitution, besides that the Constitutional Court also functions as a guardian of democracy, protecting the constitutional rights of citizens and protecting human rights. Protection of human rights is one of the functions of the Constitutional Court which is a consequence of the existence of human rights as a content of the constitution. In protecting human rights, the Constitutional Court can look at several decisions both in judicial review cases and disputes over election results
\end{abstract}


Jurnal Media Komunikasi Pendidikan Pancasila dan Kewarganegaraan

Volume 2, Nomor 1 April 2020

including restoration of the suffrage of former PKI members, the suffrage of certain ex-convicts, granting nomination rights to non-parliament parties, the right of nomination to individuals in the post-conflict local election, protection of the right to defense, the right to vote for threats and terror, protection of the right to self-destructive actions, and recognition of the methods recognized by customary law.

Keywords: Role, Court, Constitution, Election

\section{Pendahuluan}

Keberadaan konstitusi dalam suatu negara pada dasarnya memiliki kedudukan yang sangat krusial dan penting. Berlakunya suatu konsttusi sebagai hukum dasar yang mengikat didasarkan atas kekuasaan tertinggi atau prinsip kedaulatan yang dianut dalam suatu negara. Negara itu menganut paham kedaulatan rakyat, maka sumber legitimasi konstitusi itu adalah rakyat, dan jika yang berlaku itu adalah kedaulatan raja, maka raja yang menentukan berlaku tidaknya konstitusi (Asshiddiqie).

Sebagai konsekuensi dari kerangka pemikiran bahwa konstitusi merupakan hasil perjanjian bersama seluruh rakyat, yang berdasarkan teori kedaulatan rakyat merupakan pemegang kekuasaan tertinggi, maka konstitusi menduduki tempat sebagai hukum tertinggi dalam kehidupan berbangsa dan bernegara (the supreme law of the land). Bahkan, konstitusi yang secara etimologis berasal dari kata "to constitute" yang berarti membentuk, juga dapat diartikan sebagai dokumen pembentuk organisasi negara. Oleh karena itu konstitusi mengikat segenap komponen negara, baik penyelenggara maupun warga negara (Brian Thompson ).

Dengan demikian diperlukan adanya pembatasan kekuasaan, karena tanpa pembatasan kekuasaan negara pasti akan disalahgunakan. Untuk melakukan pembatasan kekuasaan negara inilah diperlukan konstitusi sebagai wujud paham konstitusionalisme, yaitu paham bahwa kekuasaan harus dibatasi agar negara dapat dijalankan sesuai dengan tujuan pembentukan negara itu sendiri. Dari sudut pandang ini, konstitusi berfungsi sebagai pembatas kekuasaan. Oleh karena itu tanpa adanya pembatasan kekuasaan, suatu konstitusi kehilangan ruh konstitusionalisme dan hanya akan menjadi legitimasi bagi kekuasaan negara yang tak terbatas.

Salah satu bentuk pembatasan kekuasaan dalam konstitusi adalah adanya jaminan perlindungan Hak Asasi Manusia (HAM). Jaminan perlindungan HAM di dalam konstitusi sebagai hukum tertinggi bermakna bahwa negara pun dilarang melakukan pelanggaran HAM dan bahkan tugas utama perlindungan HAM adalah pada negara. Oleh karena itu perkembangan paham konstitusionalisme mengandung dua esensi utama. Pertama, konsep negara hukum yang berarti bahwa hukum mengatasi kekuasaan negara dan politik. Kedua, konsep hak warga negara, bahwa kebebasan warga negara dijamin oleh konstitusi (Wignjosoebroto). Konstruksi di atas menunjukkan bahwa HAM merupakan substansi utama di dalam 
konstitusi, baik dilihat dari proses pembentukan konstitusi sebagai hasil kesepakatan bersama maupun dari sisi gagasan konstitusionalisme. Negara dibentuk sebagai wujud keinginan untuk melindungi kemanusiaan dan HAM yang tidak dapat dilakukan oleh individu sendiri atau oleh komunitas tanpa keberadaan organisasi negara. Oleh karena itu tugas utama negara yang memperoleh monopoli kekuasaan dari rakyat selaku pemegang kekuasaan tertinggi adalah untuk memenuhi dan melindungi HAM (Sabine).

Perkembangan HAM dan paham konstitusionalisme melahirkan dokumen konstitusi modern yang pada umumnya memuat jaminan perlindungan dan pemajuan HAM. Jaminan di dalam konstitusi sebagai hukum tertinggi bermakna bahwa HAM tidak dapat dilanggar atau dikesampingkan oleh aturan hukum yang lebih rendah maupun oleh tindakan negara yang harus tunduk pada konstitusi. Di sinilah dapat dilihat fungsi jaminan perlindungan dan pemajuan HAM sebagai pembatas bagi kekuasaan negara (Sri Soemantri). Bahkan, sesuai dengan hakikat HAM sebagai hak yang melekat pada keberadaan manusia sebagai karunia Tuhan YME, maka HAM bukan pemberian negara. Oleh karena itu, kalaupun di dalam hukum dan konstitusi suatu negara tidak terdapat dijamin perlindungan dan pemajuan HAM, tidak dapat menjadi dasar legitimasi adanya pelanggaran dan pengabaian terhadap HAM. HAM tetap hidup dan harus dilindung karena keberadaannya bersumber dan melekat pada keberadaan manusia bahkan sebelum terbentuknya negara. Pada posisi seperti ini HAM menjadi prinsip-prinsip universal yang menjadi landasan kritik dan kontrol terhadap konstitusi dan praktik bernegara.

\section{Pembahasan}

\section{HAM Terkait Penyelenggaraan \\ Pemilu}

Pemilu Penyelenggaraan

Pemilu sangat terkait dengan persoalan HAM. Pemilu sebagai mekanisme demokrasi modern adalah wujud dari prinsip kedaulatan rakyat yang menempatkan manusia dalam derajat yang sama. Kesederajatan tersebut mengharuskan pembentukan kekuasaan yang memonopoli dan bersifat memaksa hanya dapat dilakukan oleh atau setidak-tidaknya dengan persetujuan manusia yang diperintah. Pemilu adalah upaya mewujudkan pemerintahan dari, oleh, dan untuk rakyat. Oleh karena itu, penyelenggaraan Pemilu adalah wujud nyata pengakuan HAM dalam kehidupan bernegara.Di sisi lain, Pemilu yang demokratis hanya mungkin diselenggarakan jika ada perlindungan HAM. Pemilu membutuhkan adanya jaminan hakhak politik antara lain kebebasan berkeyakinan, kebebasan mengeluarkan pendapat, kebebasan berserikat dan berkumpul, hak persamaan dihadapan hukum dan pemerintahan serta hak pilih (Moh. Mahfud MD).

Di dalam UUD 1945 hak yang terkait dengan penyelenggaraan Pemilu adalah:

1. Pasal 27 ayat (1): Segala warga negara bersamaan kedudukannya di dalam hukum 
dan pemerintahan dan wajib menjunjung hukum dan pemerintahan itu dengan tidak ada kecualinya.

2. Pasal 28: Kemerdekaan berserikat dan berkumpul, mengeluarkan pikiran dengan lisan dan tulisan dan sebagainya ditetapkan dengan undangundang.

3. Pasal 28C ayat (2): Setiap orang berhak untuk memajukan dirinya dalam memperjuangkan haknya secara kolektif untuk membangun masyarakat, bangsa, dan negaranya.

4. Pasal 28D ayat (1): Setiap orang berhak atas pengakuan, jaminan, perlindungan, dan kepastian hukum yang adil serta perlakuan yang sama di hadapan hukum.

5. Pasal 28D ayat (3): Setiap warga negara berhak memperoleh kesempatan yang sama dalam pemerintahan.

6. Pasal 28E ayat (2): Setiap orang berhak atas kebebasan meyakini kepercayaan, menyatakan pikiran dan sikap, sesuai dengan hati nurani-nya.

7. Pasal 28E ayat (3): Setiap orang berhak atas kebebasan berserikat, berkumpul, dan mengeluarkan pendapat

8. Pasal 28I ayat (1): hak kemerdekaan pikiran dan hati nurani yang dikategorikan sebagai hak yang tidak dapat dikurangi dalam keadaan apapun.

Undang-Undang Nomor 39

Tahun 1999 tentang Hak Asasi Manusia mengatur secara khusus mengenai hak terkait penyelenggaraan Pemilu, yaitu Hak Turut Serta Dalam Pemerintahan.
Pasal 43 menyatakan Hak Turut Serta Dalam Pemerintahan meliputi:

1. Setiap warga negara berhak untuk dipilih dan memilih dalam pemilihan umum berdasarkan persamaan hak melalui pemungutan suara yang langsung, umum, bebas, rahasia, jujur dan adil sesuai dengan ketentuan peraturan perundangundangan.

2. Setiap warga negara berhak turut serta dalam pemerintahan dengan langsung atau dengan perantaraan wakil yang dipilihnya dengan bebas, menurut cara yang ditentukan dalam peraturan perundangundangan.

3. Setiap warga negara dapat diangkat dalam setiap jabatan pemerintahan.

Hak Asasi Manusia yang terkait dengan penyelenggaraan Pemilu termasuk dalam kategori hak politik. Hak dalam kategori hak politik memiliki makna bahwa hak ini telah melekat dalam status sebagai warga negara. Oleh karena itu, kewajiban negara lebih kepada melindungi (obligation to protect) agar hak itu dapat dinikmati atau dijalankan. Peran negara dalam hal ini lebih bersifat pasif, dalam arti menjaga agar tidak ada pihak lain yang melanggar hak tersebut, atau paling tinggi yang harus dilakukan negara adalah memfasilitasi penggunaan hak sehingga terdapat persamaan akses antar sesama warga negara dalam menjalankan haknya.

\section{Peran Putusan MK dalam Melindungi Hak Politik Terkait Penyelenggaraan Pemilu}

Sejak berdiri pada tahun 2003, MK telah banyak menerima 
Jurnal Media Komunikasi Pendidikan Pancasila dan Kewarganegaraan

Volume 2, Nomor 1 April 2020

permohonan pengujian UndangUndang terkait dengan penyelenggaraan Pemilu, antara lain UU Pemilihan Umum, baik Pemilu anggota DPR, DPD, DPRD; Pemilu Presiden dan Wakil Presiden; maupun Pemilu Kepala Daerah dan Wakil Kepala Daerah. Hingga saat ini pengujian terhadap UndangUndang Pemilu anggota DPR, DPD, dan DPRD telah dilakukan sebanyak 35 kali. Pengujian terhadap UndangUndang Pemilihan Presiden dan Wakil Presiden dilakukan sebanyak 18 kali. Pengujian terhadap UndangUndang Penyelenggara Pemilu sebanyak 6 kali. Pengujian terhadap Undang-Undang Pemerintahan Daerah sebanyak 43 kali. Selain itu juga terdapat Putusan-Putusan PHPU yang juga berperan dalam melindungi HAM terkait dengan penyelenggaraan Pemilu.

Beberapa putusan MK yang berperan dalam perlindungan HAM antara lain adalah sebagai berikut.

1. Pemulihan Hak Pilih Bekas Anggota Pki

Putusan Nomor 011 - 017/PUU$\mathrm{I} / 2003$ terkait dengan pengujian Undang-Undang Nomor 12 Tahun 2003 tentang Pemilihan Umum Anggota DPR, DPD, dan DPRD.16 Ketentuan yang dinyatakan bertentang dengan UUD 1945 dan tidak memiliki kekuatan hukum mengikat adalah Pasal 60 huruf g Undang-Undang Nomor 12 Tahun 2003 yang menentukan salah satu syarat menjadi calon anggota DPR, DPD, dan DPRD adalah bukan bekas anggota organisasi terlarang PKI, termasuk organisasi massanya, atau bukan orang yang terlibat langsung ataupun tak langsung dalam G30S/PKI, atau organisasi terlarang
lainnya.MK menyatakan bahwa ketentuan persyaratan tersebut bersifat diskriminatif. Di sisi lain UUD 1945 melarang diskriminasi sebagaimana dinyatakan dalam Pasal 27 ayat (1), Pasal 28D ayat (1), Pasal 28I ayat (2). Hal itu dijabarkan dalam Pasal 1 ayat (3) UndangUndang Nomor 39 Tahun 1999 tentang Hak Asasi Manusia yang tidak membenarkan diskriminasi berdasarkan perbedaan agama, suku, ras, etnik, kelompok, golongan status sosial, status ekonomi, jenis kelamin, bahasa, keyakinan politik. Ketentuan dalam Pasal 60 huruf g Undangundang Nomor 12 Tahun 2003 merupakan pembatasan hak pilih yang bersifat diskriminatif berdasarkan keyakinan politik yang pernah dianut.Larangan terhadap kelompok tertentu warga negara untuk mencalonkan diri sebagai anggota DPR, DPD, dan DPRD, seperti diatur dalam Pasal 60 huruf $g$ Undang-Undang Nomor 12 Tahun 2003 mengandung nuansa hukuman politik kepada kelompok tertentu. Sebagai konsekuensi dari prinsip negara hukum yang dianut Indonesia, seharusnya setiap pelarangan yang mempunyai kaitan langsung dengan hak dan kebebasan warga negara harus didasarkan atas putusan pengadilan yang mempunyai kekuatan hukum yang tetap.MK menyatakan ketentuan Pasal 60 huruf g Undang-Undang Nomor 12 Tahun 2003 merupakan pengingkaran terhadap hak asasi warga negara atau diskriminasi atas dasar keyakinan politik. Dengan putusan ini, para bekas anggota organisasi terlarang PKI, termasuk organisasi massanya, atau bukan orang yang terlibat langsung ataupun tak langsung 
dalam G30S/PKI, atau organisasi terlarang lainnya memperoleh haknya pilihnya kembali, terutama hak untuk dipilih sebagai calon anggota DPR, DPD, dan DPRD

2. Penggunaan KTP dalam Pemilu Presiden

Putusan selanjutnya adalah putusan terhadap ketentuan Pasal 8 dan Pasal 111 ayat (2) UndangUndang Nomor 42 Tahun 2008 tentang Pemilihan Umum Presiden dan Wakil Presiden. Pasal tersebut menyatakan bahwa warga negara yang dapat menggunakan hak memilih adalah yang telah terdaftar sebagai pemilih dalam Daftar Pemilih Tetap (DPT) yang disusun oleh KPU. Di sisi lain, masih banyak warga negara yang memenuhi syarat menjadi pemilih, tetapi tidak terdaftar sebagai pemilih dalam DPT.Di dalam putusan Nomor 102/PUU-VII/2009, MK memutuskan bahwa ketentuan Pasal 28 dan Pasal 111 ayat (1) UndangUndang Nomor 42 Tahun 2008 konstitusional bersyarat (conditionally constitutional) sepanjang tidak menghilangkan hak pilih warga negara yang tidak terdaftar dalam DPT dalam Pemilihan Umum Presiden dan Wakil Presiden. Putusan ini juga memberikan pedoman berupa syarat dan cara yang harus dipenuhi bagi warga Negara yang tidak terdaftar dalam DPT apabila akan menggunakan hak pilihnya. Pasal 28 dan Pasal 111 ayat (1) UndangUndang Nomor 42 Tahun 2008 adalah konstitusional sepanjang diartikan mencakup warga negara yang tidak terdaftar dalam DPT dengan syarat sebagai berikut:
1) Selain warga Negara Indonesia yang terdaftar dalam DPT, warga Negara Indonesia yang belum terdaftar dalam DPT dapat menggunakan hak pilihnya dengan menunjukkan Kartu Tanda Penduduk (KTP) yang masih berlaku bagi warga Negara Indonesia yang berada di luar Negeri

2) Warga negara Indonesia yang menggunakan KTP harus dilengkapi dengan Kartu Keluarga (KK) atau sejenisnya

3) Penggunaan hak pilih bagi warga negara Indonesia yang menggunakan KTP yang masih berlaku hanya dapat digunakan di Tempat Pemungutan Suara (TPS) yang berada di RT/RW atau nama sejenisnya sesuai dengan alamat yang tertera di dalam KTPnya

4) Warga Negara Indonesia sebagaimana disebutkan dalam angka 3 di atas, sebelum menggunakan hak pilihnya, terlebih dahulu mendaftarkan diri pada KPPS setempat;

5) Warga Negara Indonesia yang menggunakan hak pilihnya dengan KTP atau Paspor dilakukan pada 1 (satu) jam sebelum selesainya pemungutan suara di TPS atau TPS Luar Negeri Setempat

3. Persamaan Hak Dalam Pengajuan Pasangan Calon Pemilukada

Salah satu syarat partai politik yang dapat mengajukan pasangan 
calon kepala daerah dan wakil kepala daerah berdasarkan Penjelasan Pasal 59 ayat (1) Undang-Undang Nomor 32 Tahun 2004 adalah partai politik atau gabungan partai politik yang memiliki kursi di DPRD. Hal ini berbeda dengan bunyi ketentuan Pasal 59 ayat (1). Ketentuan Pasal 59 Undang-Undang Nomor 32 Tahun 2004 tersebut tidak memberikan batasan bahwa yang dapat mengajukan pasangan calon adalah partai politik yang memiliki kursi tersebut.

Atas dasar perbedaan yang dipandang merugikan hak konstitusional pemohon itu, diajukan permohonan pengujian UndangUndang ke MK dalam perkara Nomor 005/PUU-III/2004. MK menyatakan bahwa Penjelasan Pasal 59 ayat (1) UU Nomor 32 Tahun 2004 bertentangan dengan norma yang terkandung dalam Pasal 59 ayat (1) dan (2), dan bahkan telah menegasikan norma di dalam Pasal yang dijelaskan itu. Pasal 59 ayat (1) dan (2) Undang-Undang Nomor 32 Tahun 2004 telah jelas mengatur bahwa yang boleh mengajukan pasangan calon Kepala Daerah/Wakil Kepala Daerah adalah partai politik atau gabungan partai politik yang memperoleh $15 \%$ kursi di DPRD "atau" yang memperoleh $15 \%$ akumulasi suara dalam pemilu anggota DPRD di daerah yang bersangkutan. Kata "atau" dalam Pasal 59 ayat (2) merujuk pada alternatif di antara dua pilihan yang disebut sebagai sikap akomodatif terhadap semangat demokrasi yang memungkinkan bagi calon dari partai yang tidak memiliki kursi di DPRD tetapi memiliki akumulasi suara $15 \%$ atau pun calon independen sepanjang diajukan oleh partai atau gabungan partai untuk turut serta dalam Pilkada langsung.

Dalam pertimbangan hukum Putusan Nomor 005/PUU-III/2005 MK menyatakan bahwa penjelasan berfungsi untuk menjelaskan substansi norma yang terdapat dalam pasal dan tidak menambahkan norma baru, apalagi memuat substansi yang sama sekali bertentangan dengan norma yang dijelaskan. Hal itu telah diabaikan oleh pembentuk undangundang dalam merumuskan Penjelasan Pasal 59 ayat (1) UU Nomor 32 Tahun 2004 dengan cara membuat Penjelasan Pasal 59 ayat (1) memuat norma baru yang berbeda maknanya dengan norma yang terkandung dalam Pasal 59 ayat (1) dan (2) yang sudah jelas.

Adanya pertentangan antara substansi Pasal 59 ayat (1) dan ayat (2) Undang-Undang Nomor 32 Tahun 2004 dengan Penjelasan Pasal 59 ayat (1) Undang-Undang Nomor 32 Tahun 2004 mengandung inkonsistensi yang melahirkan interpretasi ganda, dan menyebabkan keragu-raguan dalam pelaksanaanya serta memunculkan ketidakpastian hukum. Hal itu menurut MK dapat menimbulkan pelanggaran terhadap hak konstitusional sebagaimana diatur dalam Pasal 28D ayat (1) UUD 1945.

Di sisi lain, MK juga menyatakan bahwa Penjelasan Pasal 59 ayat (1) UU Nomor 32 Tahun 2004 telah menghilangkan hak Para Pemohon untuk dipilih sebagai kepala daerah yang telah dijamin secara tegas dalam rumusan Pasal 59 ayat (2). Oleh karena itu, hak konstitusional Pemohon untuk berpartisipasi dalam pemerintahan 
yang dijamin oleh Pasal 28D ayat (3) UUD 1945 dan dijabarkan dalam Pasal 59 ayat (1) dan (2) UU Pemda dilanggar atau dihilangkan oleh Penjelasan Pasal 59 ayat (1). MK memutuskan untuk menyatakan bahwa penjelasan Pasal 59 ayat (1) Undang-Undang Nomor 32 Tahun 2004 bertentangan dengan UUD 1945 dan menyatakan tidak lagi mempunyai kekuatan hukum mengikat.
4. Pengakuan
Calon

Perseorangan

Putusan selanjutnya adalah terkait dengan keberadaan calon perseorangan dalam pemilihan kepala daerah dan wakil kepala daerah. Putusan ini mengalami perkembangan dari semula MK menyatakan bahwa ketentuan yang menyatakan bahwa pencalonan hanya melalui partai politik tidak bertentangan dengan UUD 1945 karena merupakan wilayah kebijakan hukum (legal policy)pembentukan undang-undang, kemudian berkembang dengan putusan yang mengharuskan calon perseorangan diakomidir dalam pemilihan kepala daerah dan wakil kepala daerah.Putusan yang menyatakan bahwa pembatasan pengajuan calon hanya melalui partai politik tidak bertentangan dengan UUD 1945 adalah Putusan 006/PUU-III/2005. Ketentuan pembatasan itu merupakan penjabarandari Pasal 18 Ayat (4) UUD 1945 dalam bentuk pengaturan mekanisme rekrutmen jabatan pemerintahan yang tidak bertentangan dengan prinsip nondiskriminasi yang dianut UUD 1945.

Dalam pertimbangan hukum Putusan Nomor 005/PUU-III/2005 dinyatakan bahwa prinsip persamaan kedudukan dan kesempatan dalam pemerintahan yang diartikan juga tanpa diskriminasi adalah merupakan hal yang berbeda dengan mekanisme rekrutmen dalam jabatan pemerintahan yang dilakukan secara demokratis. Hak setiap orang untuk memperoleh kesempatan yang sama dalam pemerintahan dilindungi oleh Konstitusi sepanjang orang tersebut memenuhi syarat-syarat yang ditentukan dalam undang-undang yang berkenaan dengan itu, antara lain syarat usia, pendidikan, kesehatan jasmani dan rohani serta syarat-syarat lainnya. Persyaratan tersebut berlaku sama terhadap semua orang, tanpa membedabedakan orang baik karena alasan agama, suku, ras, etnik, kelompok, golongan, status sosial, status ekonomi, jenis kelamin, bahasa dan keyakinan politik sehingga tidak bersifat diskriminatif sebagaimana diatur dalam Pasal 27 ayat (1) dan 28D ayat (3) UUD 1945 yang dijabarkan lebih jauh dalam Pasal 1 ayat (3) Undang-undang Nomor 39 Tahun 1999 tentang Hak Asasi Manusia.

Terhadap keberadaan calon perseorangan dalam pemilihan kepala daerah dan wakil kepala daerah, mengalami perkembangan dalam Putusan MK Nomor 5/PUUV/2007. Dalil utama pemohon dalam perkara ini adalah bahwa ketentuan pembatasan pasangan calon pemilihan kepala daerah dan wakil kepala daerah hanya diajukan oleh partai politik atau gabungan partai politik telah membatasi hak seseorang untuk mengajukan diri sebagai pasangan calon kepala daerah. 
MK mengabulkan permohonan Pemohon.MK berpendapat pencalonan kepala daerah dan wakil kepala daerah secara perseorangan di luar Provinsi Nanggroe Aceh Darusalam harus dibuka agar tidak terdapat dualisme dalam melaksanakan ketentuan Pasal 18 Ayat (4) UUD 1945 karena dualisme tersebut dapat menimbulkan terlanggarnya hak warga negara yang dijamin oleh Pasal 28D Ayat (1) dan Ayat (3) UUD 1945.

5. Hak Pilih Mantan Terpidana

Selanjutnya adalah terkait dengan persyaratan calon tidak pernah dipidana karena melakukan tindak pidana yang diancam dengan pidana penjara 5 tahun atau lebih. Seperti halnya dengan putusan terkait dengan calon perseorangan, substansi putusan ini juga mengalami perkembangan dari sisi amar putusan.

Dalam pertimbangan hukum Putusan Nomor 14-17/PUU-V/2007 ini MK berpendapat bahwa jabatan publik adalah jabatan kepercayaan (vertrouwenlijk-ambt) sehingga setiap calon pejabat publik harus memenuhi persyaratan-persyaratan tertentu. Pencalonan seseorang untuk mengisi suatu jabatan publik dengan tanpa membeda-bedakan orang sebagaimana dijamin UUD 1945 tidaklah berarti bahwa negara tidak boleh mengatur atau menentukan persyaratannya, sepanjang pengaturan dan/atau persyaratan itu merupakan tuntutan objektif yang dibutuhkan oleh suatu jabatan atau aktivitas pemerintahan tertentu dan sepanjang tidak bersifat diskriminatif dalam pengertian tidak membedabedakan orang atas dasar agama, ras, suku, bahasa, jenis kelamin, keyakinan politik, atau status sosial tertentu lainnya.

Berdasarkan pertimbangan tersebut, MK menyatakan bahwa ketentuan syarat tidak pernah dipidana adalah konstitusional bersyarat (conditionally constitutional). Dengan demikian syarat tidak pernah dipidana adalah konstitusional sepanjang tidak mencakup pidana yang terjadi karena kealpaan dan tindak pidana politik. Secara lebih rinci, penentuan persyaratan tidak pernah dipidana penjara karena melakukan tindak pidana yang diancam dengan pidana penjara 5 tahun atau lebih untuk menduduki suatu jabatan publik adalah konstitusional hanya jika:

1) Rumusan dalam Pasal 6 huruf $t$ UU Pilpres, Pasal 16 Ayat (1) huruf d UU MK, Pasal 7 Ayat (2) huruf d UU MA, Pasal 58 huruf $f$ UU Pemda, Pasal 13 huruf $g$ UU BPK tersebut tidak mencakup tindak pidana yang timbul karena kealpaan ringan (culpa levis), meskipun ancaman pidananya 5 (lima) tahun atau lebih.

2) Rumusan dalam Pasal 6 huruf $t$ UU Pilpres, Pasal 16 Ayat (1) huruf d UU MK, Pasal 7 Ayat (2) huruf d UU MA, Pasal 58 huruf $f$ UU Pemda, Pasal 13 huruf g UU BPK tersebut tidak mencakup kejahatan politik

Putusan senada juga dijatuhkan terhadap pengujian Pasal 50 ayat (1) huruf g Undang-Undang Nomor 10 Tahun 2008 tentang Pemilihan Umum Anggota DPR, DPD, dan DPRD dalam Perkara Nomor 15/PUU - VI/2008 yang memuat syarat tidak pernah dijatuhi pidana penjara berdasarkan putusan 
pengadilan yang telah memiliki kekuatan hukum tetap karena melakukan tindak pidana yang diancam dengan pidana penjara 5 tahun atau lebih. Di dalam putusan ini MK menegaskan salah satu prinsip hukum tentang keadilan yang menjadi dasar putusan, yaitu bahwa Keadilan bukanlah selalu berarti memperlakukan sama terhadap setiap orang. Keadilan dapat berarti memperlakukan sama terhadap halhal yang memang sama dan memperlakukan berbeda terhadap hal-hal yang memang berbeda.

Perkembangan lebih lanjut terkait dengan syarat tidak pernah dipidana terbentuk melalui Putusan MK Nomor 04/PUU-VII/2009 yang menguji persyaratan itu di dalam Pasal 12 huruf g dan Pasal 50 ayat (1) huruf g UU Nomor 10 Tahun 2008 tentang Pemilihan Umum Anggota DPR, DPD, dan DPRD, dan Pasal 58 huruf $\mathrm{f}$ Undang-Undang Nomor 12 Tahun 2008 tentang Perubahan Kedua atas UndangUndang Nomor 32 Tahun 2004 tentang Pemerintahan Daerah. Di dalam Putusan ini MK menegaskan bahwa Putusan sebelumnya, yaitu Putusan Nomor 14-17/PUU-V/2007 tidak dapat digeneralisasi untuk semua jabatan publik, melainkan hanya untuk jabatan publik yang dipilih (elected officials), karena terkait dengan pemilihan umum yang secara universal menganut prinsip bahwa peniadaan hak pilih itu hanya karena pertimbangan ketidakcakapan, keadaan sakit jiwa, serta ketidakmungkinan (impossibility) misalnya karena telah dicabut hak pilihnya oleh putusan pengadilan yang mempunyai kekuatan hukum tetap. Oleh karena itu pelarangan terhadap seseorang yang pernah dipidana penjara karena melakukan tindak pidana yang diancam hukuman 5 tahun atau lebih melanggar prinsip hukum Pemilu, serta bertentangan dengan asas persamaan dihadapan hukum (equality before the law) serta melanggar hak untuk

\section{Kesimpulan}

Konstitusi lahir dari perjanjian social yang menempatkan kesederajatan manusia sebagai prinsip utama. Berdasarkan perspektif teori demokrasi negara hukum, konstitusi lahir sebagai bentuk pengakuan terhadap HAM. Oleh karena itu, salah satu materi muatan konstitusi yang penting adalah adanya jaminan perlindungan dan kemajuan HAM yang sekaligus menjadi tanggung jawab negara untuk memenihunya serta menjadi pembatas bagi kekuasaan negara itu sendiri.

Keberadaan MK dikateri oleh pemikiran perlunya di bentuk pengadilan konstitusi untuk menjadi prinsip supremasi konstitusi. Sesuai dengan substansi yang terkandung dalam konstitusi, salah satu fungsi yang dimiliki oleh MK adalah untuk melindungi HAM. Fungsi ini dijadikan melalui wewenang yang dimiliki, terutama wewenang menguji Undang-Undang dan memutus PHPU yang telah dijalankan oleh MK.

Putusan-putusan MK baik dalam perkara PUU maupun PHPU telah berperan dalam melindungi HAM terkait dengan penyelenggaraan pemilu. Hal ini antara lain dalam bentuk putusan yang mengembalikan hak pilih bekas anggota PKI, 
Jurnal Media Komunikasi Pendidikan Pancasila dan Kewarganegaraan

Volume 2, Nomor 1 April 2020

pengambilan hak pilih mantan narapidana tertentu, dan lain-lain serta pengakuan terhadap cara yang diakui oleh hukum adat.

\section{Daftar Pustaka}

Asshiddiqie. Membangun Budaya Sadar Konstitusi, Mahkamah Konstitusi Republik Indonesia.

Brian Thompson, Texboook on Constitutional and Administrave law, London : Black press 1td., 1997.

Eprge H. Sabine, A History of Political Theory, Third Edition, New York-Chaniago-San Fransisco- Toronto-London : Holt, Rinehart amd Wiston, 1961.

Mangku, D. G. S. (2010). Pelanggaran terhadap Hak Kekebalan Diplomatik (Studi Kasus Penyadapan Kedutaan Besar Republik Indonesia (KBRI) di Yangon Myanmar berdasarkan Konvensi Wina 1961). Perspektif, 15(3).

Mangku, D. G. S. (2011). Peluang dan Tantangan ASEAN Dalam Penyelesaian Sengketa Kuil Preah Vihear Di Perbatasan Kamboja dan Thailand. Pandecta: Research Law Journal, 6(2).

Mangku, D. G. S. (2012). Suatu Kajian Umum tentang Penyelesaian Sengketa Internasional Termasuk di Dalam Tubuh ASEAN. Perspektif, 17(3).

Mangku, D. G. S. (2013). Kasus Pelanggaran Ham Etnis Rohingya: Dalam Perspektif ASEAN. Media Komunikasi FIS, 12(2).
Mangku, D. G. S. (2017). The Efforts of Republica Democratica de Timor-Leste (Timor Leste) to be a member of Association of Southeast Asian Nations (ASEAN) and take an active role in maintaining and creating the stability of security in Southeast Asia. Southeast Asia Journal of Contemporary Business, Economics and Law, 13(4), 18-24.

Mangku, D. G. S. (2018). Kepemilikan Wilayah Enclave Oecussi Berdasarkan Prinsip Uti Possidetis Juris. Jurnal Advokasi, 8(2), 150-164.

Mangku, D. G. S. (2018). Legal Implementation On Land Border Management Between Indonesia And Papua New Guinea According to Stephen B. Jones Theory. Veteran Law Review, 1(1), 72-86.

Mangku, D. G. S., \& Itasari, E. R. (2015). Travel Warning in International Law Perspective. International Journal of Business, Economics and Law, 6(4).

Mangku, D. G. S., \& Radiasta, I. K. (2019). Tanggung Jawab Negara terhadap Penembakan Pesawat MH17 berdasarkan Hukum Internasional. Pandecta: Research Law Journal, 14(1), 25-33.

Moh, Mahfud MD, Hukum dan Pilar-pilar Demokrasi, Yogyakarta : Gama Media, 1999.

Sakti, L. S., Mangku, D. G. S., \& Yuliartini, N. P. R. (2020). Tanggung Jawab Negara 
Jurnal Media Komunikasi Pendidikan Pancasila dan Kewarganegaraan

Volume 2, Nomor 1 April 2020

Terhadap Pencemaran

Tumpahan Minyak Di Laut

Perbatasan Indonesia Dengan

Singapura Menurut Hukum

Laut Internasional. Jurnal

Komunitas Yustisia, 2(3), 131140.

Setiawati, N., Mangku, D. G. S., \& Yuliartini, N. P. R. (2020). Penyelesaian Sengketa

Kepulauan Dalam Perspektif Hukum Internasional (Studi Kasus Sengketa Perebutan Pulau Dokdo antara JepangKorea Selatan). Jurnal Komunitas Yustisia, 2(2), 241250.

Soetandyo Wignjosoebroto, Hukum :

Pradigma, Metode, dan

Dinamika Masalahnya, Jakarta:

ELSAM dan HUMA, 2002.

Sri Soemantri, Prosedur dan Sistem

Perubahan

Bandung : Alumni 1984.

Widayanti, I. G. A. S., Mangku, D. G. S., SH, L. M., Yuliartini, N.

P. R., \& SH, M. (2019).

Penggunaan Tentara Anak

Dalam Konflik Bersenjata

Ditinjau Dari Perspektif

Hukum Humaniter (Studi

Kasus: Konflik Bersenjata Di

Sri Lanka). Jurnal Komunitas Yustisia, 2(1).

Wiratmaja, I. G. N. A., Mangku, D. G. S., \& Yuliartini, N. P. R. (2020). Penyelesaian Sengketa Maritime Boundary

Delimitation Di Laut Karibia Dan Samudera Pasifik Antara Costa Rica Dan Nicaragua Melalui Mahkamah Internasional. Jurnal

Komunitas Yustisia,2(1), 6069.
Yuliartini, N. P. R., \& Mangku, D. G. S. (2019). Tindakan Genosida terhadap Etnis Rohingya dalam Perspektif Hukum Pidana Internasional. Majalah Ilmiah Cakrawala Hukum, 21(1), 4149. 